DOI: 10.36695/2219-5521.4.2019.70

УДК 342.61

\title{
T.А. БАРІЛОВСЬКА
}

Таїсія Андріївна Баріловська, студентка Інституту післядипломної освіти Київського національного університету імені Тараса Шевченка*

ORCID: 0000-0002-9472-9593

\section{ЗОВНІШНІ ФУНКЦІЇ ПРЕЗИДЕНТА УКРАЇНИ В КОНТЕКСТІ ЗАБЕЗПЕЧЕННЯ БЕЗПЕКИ ДЕРЖАВИ}

Постановка проблеми. Актуальність теми зумовлена особливим конституційним положенням Президента України в системі державної влади України. Так, Президент є гарантом Конституції України, прав і свобод людини і громадянина, незалежності України та цілісності її території1. Саме він виступає головною силою, яка задає загальний вектор роботи всього державного механізму. У силу цього функції та правовий статус Президента України мають бути особливо ретельно продуманими.

Разом із тим, правове регулювання діяльності Президента України поки не володіє достатнім рівнем розгорнутості, глибини та впорядкованості. Норми, що становлять інститут президентства, містяться у великій кількості різних правових актів, слабо систематизовані. Збереження недоліків названого регулювання визначається, поряд з іншими причинами, недостатнім науковим опрацюванням питань про місце та роль Президента в системі влади в Україні, природі й елементному складі його статусу. Вимагають подальшого вивчення питання про значення і зміст конституційних норм, присвячених Президенту України, функцій, повноважень, напрями його внутрішньої систематизації.

Аналіз останніх досліджень і публікацій. Вчені - теоретики держави і права, конституційного, адміністративного права та права публічного управління у монографіях, підручниках та наукових статтях розробили теоретичні основи вчення про державну владу, витоки становлення державності, базові засади конституційного права України, а також окремих інститутів конституційного права, включаючи інститут президентства. Серед науковців, які досліджували питання правового статусу Президента України, його функцій, повноважень, необхідно назвати таких, як: Ю. Барабаш, Д. Бєлов, Ф. Бурчак, О. Даниляк, А. Кудряченко, В. Скрипнюк, О. Спірін, В. Сухонос, Ю. Тодика, А. Яковлєв, Ю. Михайлова, П. Рудик, В. Сазонов та багатьох інших.

Формулювання мети статті. Мета статті полягає у з'ясуванні зовнішніх функцій Президента України в контексті забезпечення безпеки держави.

Виклад основного матеріалу. Сучасний світ переживає фундаментальні й динамічні зміни, які глибоко зачіпають інтереси України, ії громадян. Глобалізація світової економіки, що породжує ризик залежності економічної системи України від впливу ззовні, загострення проблеми нерозповсюдження зброї масового знищення, зростання міжнародного тероризму, прагнення окремих держав перетворити світ в однополярний - це далеко не повний перелік тенденцій, що загрожують міжнародному миру і безпеці в цілому та нашій державі зокрема.

Аналіз теоретичних основ такого роду діяльності передбачає врахування взаємозв'язку нових тенденцій і перспектив розвитку України і міжнародного життя в контексті динамічного оновлення, що носить відбиток наступності українського зовнішньополітичного курсу. Юридична наука досить активно оперує поняттям «функція». Дана категорія не завжди використовується законодавцем при формуванні компетенції державних органів, посадових осіб, але завжди мається на увазі при закріпленні за учасниками правових відносин певних повноважень. Конституція України практично не використовує таку категорію, як функція.

Законодавець не застосовує термін «функція» при характеристиці напрямів діяльності виконавчих органів влади. Закріплюючи компетенцію вищих органів державної влади, він оперує такими правовими кон-

(C) Т.А. Баріловська, 2019

* Taisiia Barilovska, student of the Institute of Postgraduate Education of Taras Shevchenko National University of Kyiv 
струкціями, як «загальні повноваження», «повноваження», «питання», «предмети ведення, управління» тощо ${ }^{2}$

У функціях глави держави відбивається соціальне призначення цього інституту, об'єктивна необхідність здійснення ним суспільно корисної, соціально обумовленої представницької й правотворчої діяльності. Правильне розуміння функцій глави держави є важливим і для практики державно-правового будівництва, оскільки точне їх визначення сприяє виразному визначенню цього інституту при реалізації державних функцій. Без вирішення питання про функції глави держави важко окреслити пріоритетні напрями та обсяг, характер і зміст його діяльності.

З урахуванням того, що функції Президента визначають основні напрями його діяльності, в юридичній літературі, існує низка підстав для їх класифікації. Для прикладу розглянемо одну із них. Зокрема, В. Погорілко, розглядаючи питання класифікації функцій Президента, пропонує таку типологію для класифікації:

- за об’єктом (сферою діяльності, об'єктні функції) - зовнішні та внутрішні функції держави;

- за способами, засобами й умовами діяльності (владні функції) - законодавчу, виконавчу, судову і контрольно-наглядову функції3.

Механізм здійснення зовнішніх функцій Української держави відрізняється складною структурою відносин, що знаходяться у взаємозв'язку і взаємодії. Особливе місце в розглянутому механізмі займає Президент України, який відповідно до закріплених у Конституції України і законодавстві повноважень очолює даний механізм і координує роботу його ланок.

Зовнішньополітична діяльність Президента України грунтується на загальних принципах поділу влади, верховенства закону, конституційної відповідальності, а також на спеціальних принципах єдності зовнішньої політики і підтримки зовнішньополітичного курсу4 3 метою вдосконалення роботи очолюваного Президентом України механізму здійснення зовнішніх функцій держави необхідні заходи, спрямовані на активізацію зовнішньополітичної діяльності й підвищення самостійності Уряду України, розвиток наукової складової даного механізму.

Процес здійснення зовнішніх функцій держави передбачає наявність відповідного механізму, що включає в себе різнорідні за своїм завданням, правовим статусом, організацією та іншими ознаками елементи, які, в свою чергу, взаємопов'язані та взаємодіють між собою. Президент України займає особливе місце в цьому механізмі. Відповідно до Конституції України він здійснює керівництво зовнішньою політикою країни і як глава держави представляє Україну в міжнародних відносинах 5 .

З урахуванням конституційних положень, виходячи зі спрямованості й форм здійснення Президентом України своїх повноважень у зовнішньополітичній сфері, правомірно виділити наступні групи його повноважень у сфері здійснення зовнішніх функцій України:

1) щодо визначення основних напрямів зовнішньої політики;

2)за поданням України в міжнародних відносинах;

3) у сфері оборони країни 6 .

Характер даних повноважень, їх коло і зміст визначаються особливою роллю Президента в державному механізмі. Разом із тим це не означає, що зовнішньополітичні повноваження глави держави носять абсолютний характер. Він покликаний здійснювати керівництво зовнішньою політикою, вступаючи у взаємини 3 іншими органами державної влади на основі загальних конституційних принципів - поділу влади, верховенства закону, конституційної відповідальності.

Елементи конституційно-правового статусу Президента України за їх значенням можна розділити на основні і додаткові (службові). До першої групи входять ціннісно-функціональне призначення Президента, його повноваження, публічні права. До додаткових елементів слід віднести забезпечення виконання функцій і повноважень Президента, гарантії його діяльності й відповідальність. У числі основних елементів статусу Президента України особливо виділяється ціннісно-функціональне призначення Президента, що є головним системоутворюючим елементом названого статусу7.

Президент України має можливості для ефективного здійснення своєї ідеологічної функції. Це - його виступи з доповідями на різного роду форумах, затвердження державних програм, концепцій та директив. Значні можливості випливають з його права підписувати закони, прийняті Парламентом країни. У порядку, встановленому Конституцією, він має право повернути закон або окремі його положення зі своїми запереченнями. Він має право скасовувати акти Уряду, призупиняти рішення місцевих Рад депутатів та скасовувати рішення місцевих виконавчих і розпорядчих органів у разі невідповідності їх законодавству. Все це відіграє колосальну роль у здійсненні ним не лише внутрішніх, а й зовнішніх функцій.

На прикладі України можна простежити функції гарантування безпеки саме Президентом України. Сучасний етап розвитку України та антитерористичної операції, яка затягнулася на кілька років, дає змогу побачити та зрозуміти роль зовнішніх функцій Президента України у контексті забезпечення безпеки. Акції терористичних організацій спрямовані не тільки на загострення обстановки в конкретному регіоні, а й на захоплення влади, територіальний переділ, насильницьку зміну конституційного ладу.

Слід також зазначити, що зважаючи на значні труднощі, проблема боротьби 3 тероризмом повинна носити загальнодержавний характер. Попередження тероризму має включати широке коло соціальних, політичних, економічних, юридичних та інших перетворень на основі ретельно опрацьованих з кримінологічної точки зору і всебічно обгрунтованих рішень. Важливим аспектом є міжнародне співробітництво в боротьбі 3 тероризмом. Боротьба з тероризмом спонукає світову спільноту до пошуку шляхів проведення скоордино- 
ваної діяльності та вироблення єдиної концепції боротьби з тероризмом. Саме тут і включається Президент України з виконанням своїх зовнішніх функцій ${ }^{8}$.

Тероризм становить загрозу національній безпеці Україні в духовній сфері, порушуючи збереження i зміцнення моральних цінностей суспільства, традицій патріотизму і гуманізму, культурного потенціалу країни. Терористичні виклики ускладнюють духовне відродження багатонаціонального народу України, несуть загрозу конституційним правам і свободам людини і громадянина у сфері духовного життя, а також індивідуальній, груповій та громадській свідомості9.

Щодо суб'єктів та об'єктів стратегічного планування, то відповідно до чинного законодавства суб'єктами стратегічного планування у сфері національної безпеки в межах наданих повноважень $є$ :

- Верховна Рада України;

- Президент України;

- Кабінет Міністрів України;

- Рада національної безпеки і оборони України;

- центральні органи виконавчої влади, які здійснюють керівництво Збройними Силами України та іншими військовими формуваннями; Генеральний штаб Збройних Сил України;

- місцеві державні адміністрації та органи місцевого самоврядування;

- урядові комісії, міжгалузеві та відомчі робочі групи ${ }^{10}$.

Цей фактор знову ж таки підкреслює функцію забезпечення безпеки Президентом України, в тому числі і на міжнародному рівні. Президент України є гарантом державного суверенітету, територіальної цілісності України. Щодо виконання цієї функції Президент України вносить до Верховної Ради України подання про оголошення стану війни та в разі збройної агресії проти України приймає рішення про використання Збройних Сил України та інших утворених відповідно до законів України військових формувань; приймає відповідно до закону рішення про загальну або часткову мобілізацію та введення воєнного стану в Україні або в окремих ii місцевостях у разі загрози нападу, небезпеки державній незалежності України; є Верховним Головнокомандувачем Збройних Сил України; призначає на посади та звільняє з посад вище командування Збройних Сил України, інших військових формувань; здійснює керівництво у сферах національної безпеки та оборони держави.

Повноваження Президента України у сфері оборони країни, будучи тісно пов'язані з іншими зовнішньополітичними повноваженнями глави держави, мають свою специфіку. Вони схильні до більш жорсткого й детального правового регулювання, грунтуються, поряд із загальними конституційними принципами, також на таких спеціальних принципах, як єдність політичного і військового керівництва, підконтрольність військових структур главі держави, централізація державного управління Збройними Силами України; повноваження, пов'язані із застосуванням заходів щодо відображення агресії або ліквідації ії безпосередньої загрози, мають тимчасовий характер.

Висновки. Логіка сучасного етапу розвитку міждержавних відносин переконливо підтверджує, що 3 метою ефективного зміцнення загального миру і міжнародної безпеки обов'язково повинна бути вироблена єдина стратегія взаємодії та регламентації зовнішніх функцій та повноважень президентів на міжнародному рівні в питаннях забезпечення цієї безпеки.

Мабуть, однією з найважливіших функцій в діяльності Президента України на міжнародному рівні є саме зовнішня функція щодо забезпечення безпеки. Поки держава не буде мати безпеку власної території, кордонів, не будуть важливі інші функції, адже саме безпека є гарантом стабільності, а отже, і можливістю забезпечення інших функцій.

1 Див.: Конституція України. Відомості Верховної Ради Украӥни. 1996. № 30. Ст. 141.

2 Див.: Погорілко В.Ф., Федоренко В.Л. Конституційне право України. Київ: Наук. думка, 2007. 338 с.

3 Там само.

4 Теоретико-методологічні засади забезпечення національної безпеки держави у ії визначальних сферах : монографія / В.Ю. Богданович, А.І. Семенченко, Ю.В. Сгоров, О.О. Бортник. Київ : Кий, 2007. 370 с.

5 Див.: Конституція України. Відомості Верховної Ради Украӥни. 1996. № 30. Ст. 141

6 Див.: Погорілко В.Ф., Федоренко В.Л. Конституційне право України. Київ: Наук. думка, 2007. 338 с.

7 Див.: Сухонос В.В. Механізм реалізації функцій голови держави. Правовий вісник Украйнської академії банківської справи. 2010. № 1 (3). С. 8-14.

8 Див.: Власюк О.С. Національна безпека України: еволюція проблем внутрішньої політики: вибр. наук. пр. Київ: НІСД, 2016. $527 \mathrm{c}$.

9 Див.: Ковбасюк Ю.В., Ситник Г.П. Виклики й загрози національній безпеці у контексті геополітичного та геоекономічного вибору України: матеріали круглого столу (Київ, 3 груд. 2014 р.) / Нац. акад. держ. упр. при Президентові України, Каф. глобалістики, євроінтеграції та упр. нац. безпекою. Київ: НАДУ, 2014. 161 с.

10 Див.: Про національну безпеку України: Закон України від 21.06. 2018 р. № 2469-VIII. URL: https://zakon.rada.gov.ua/ laws/show/2469-19

\section{References:}

Konstytutsiia Ukrainy. (1996). Vidomosti Verkhovnoi Rady Ukrainy [in Ukrainian].

Bohdanovych, V.Y., Semenchenko, A.I., Yehorov, Y.V., Bortnyk, O.O. (2007). Teoretyko-metodolohichni zasady zabezpechennia natsionalnoi bezpeky derzhavy u yii vyznachalnykh sferakh. Kyiv: KYI [in Ukrainian]. 
Pohorilko, V.F., Fedorenko, V.L. (2007). Konstytutsiine pravo Ukrainy. Kyiv: Nauk. dumka [in Ukrainian].

Sukhonos, V.V. (2010). Mekhanizm realizatsii funktsii holovy derzhavy. Pravovyi visnyk Ukrainskoi akademii bankivskoi spravy. 5(3), 8-14 [in Ukrainian].

Vlasiuk, O S. (2016). Natsionalna bezpeka Ukrainy: evoliutsiia problem vnutrishnoi polityky. Kyiv: NISD [in Ukrainian].

Kovbasiuk, Y.V., Sytnyk, H.P. (2014). Vyklyky y zahrozy natsionalnii bezpetsi u konteksti heopolitychnoho ta heoekonomichnoho vyboru Ukrainy: materialy kruhloho stolu. Kyiv: NADU [in Ukrainian].

Pro natsionalnu bezpeku Ukrainy: Zakon Ukrainy (2018, June 21). № 2469-VIII [in Ukrainian].

\section{Резюме}

Баріловська T.A. Зовнішні функції Президента України в контексті забезпечення безпеки держави.

У статті досліджено роль та статус Президента України в контексті забезпечення безпеки держави на прикладі здійснення зовнішньої функції. Розкрито позиції щодо гарантування безпеки України на міжнародному рівні в контексті реалізації Президентом України своїх повноважень у сфері безпеки та оборони країни.

Ключові слова: національна безпека, Президент України, повноваження, функції, зовнішня функція, функції Президента України.

\section{Резюме}

Бариловская T.A. Внешние функции Президента Украины в контексте обеспечения безопасности государства.

В статье исследованы роль и статус Президента Украины в контексте обеспечения безопасности государства на примере осуществления внешней функции. Раскрыты позиции по обеспечению безопасности Украины на международном уровне в контексте реализации Президентом Украины своих полномочий в сфере безопасности и обороны страны.

Ключевые слова: национальная безопасность, Президент Украины, полномочия, функции, внешняя функция, функции Президента Украины.

\section{Summary}

Taisiia Barilovska. External functions of the President of Ukraine in the context of ensuring the security of the state. of the state.

The purpose of the article is to clarify the external functions of the President of Ukraine in the context of ensuring the security

The mechanism of performing the external functions of Ukraine is characterized by the complex structure of interrelated and interacting relations. Of particular importance in this mechanism is the President of Ukraine, who, in accordance with the powers enshrined in the Constitution of Ukraine and Ukrainian legislation, heads this mechanism and coordinates the operation of its parts.

The foreign policy activities of the President of Ukraine are based on the general principles of separation of powers, of the rule of law, of constitutional responsibility, and on the specific principles of the unity and of the support of foreign policy. In order to improve the operation of the mechanism of implementing foreign policy, headed by the President of Ukraine, the measures aimed at intensifying foreign policy activities and enhancing the independence of the Government of Ukraine and developing the scientific component of this mechanism are required.

The process of performing external functions of the state implies the existence of an appropriate mechanism. The mechanism of performing Ukraine's external functions includes elements that are heterogeneous in their task, legal status, organization and other characteristics, which in their turn are interrelated and interacting. The President of Ukraine has a special place in this mechanism. In accordance with the Constitution of Ukraine, he directs the foreign policy of the country and as a head of state represents Ukraine in international relations.

The logic of the current stage of the development of interstate relations strongly confirms that in order to effectively strengthen the common peace and international security, a unified strategy of interacting and regulating the external functions and powers of the presidents at the international level in ensuring this security must be developed.

Perhaps, one of the most important functions of the President of Ukraine at the international level is the external function of ensuring the security of the state. Until the state has the security of its own territory and borders, other functions do not matter, because security is the guarantee of the stability, and therefore, the possibility of ensuring other functions.

Key words: national security, President of Ukraine, powers, functions, external function, functions of the President of Ukraine. 